\title{
THE NEW RESPONDS TOWARD THE CHALLENGE: ISLAMIC DA'WAH AND CATHOLIC MISSION IN SEMARANG, 1890s-1940s
}

\author{
Mukhamad Shokheh \\ History Department, Faculty of Social Sciences, Semarang State University \\ shokheh_unnes@yahoo.co.id
}

\begin{abstract}
This study discusses the growth and development of religious movements and their effects on social life of religious communities during the period 1890s-1940s Semarang. The main problems of this study are the growth and development of Islamic da'wah and Catholic mission and its influence on socio-religious life to the people in Semarang. This study used the historical method in order to answer the problem. The development of Islamic da'wah and Catholic missions in Semarang in the period 1890s-1940s could be seen into two mainstream, namely the renewal of $d a^{\prime} w a h$ and indigenization of mission. Islamic da'wah and Catholic mission have brought progress to the social religious life of societies. Poeple in Semarang recognized the religious organization and new forms of leadership which more rational and democratic, and the growth of new awareness of identity from people to the identity as citizens.
\end{abstract}

Key words: Da'wah, mission, renewal and indigenization

\begin{abstract}
ABSTRAK
Penelitian ini mendiskusikan muncul dan berkembangnya gerakan keagamaan dan dampaknya pada kehidupan sosial pada komunitas agama periode 1890-an sampai 1940-an di Kota Semarang. Permasalahan utama dalam penelitian ini adalah pertumbuhan dan perkembangan dakwah Islam dan misi Katolik, serta pengaruhnya terhadap kehidupan sosial keagamaan di Semarang. Penelitian ini menggunakan metode sejarah untuk menjawab permasalahan. Perkembangan dakwah Islam dan misi Katolik pada periode 1890-an sampai 1940-an dapat dilihat dari dua mainstream, yakni pembaharuan dakwah dan indigenisasi (pelokalan) dari misi. Dakwah Islam dan misi Katolik memberikan progress terhadap kehidupan sosial keagamaan di Semarang. Masyarakat di Semarang mengenal organisasi keagamaan dan bentuk baru dari kepemimpinan yang lebih rasional dan demokratis, dan tumbuhnya kesadaran atas identitas personal menjadi identitas sebagai warga masyarakat.
\end{abstract}

Kata kunci: Dakwah, misi, pembaruan, dan indigenisasi

\section{INTRODUCTION}

Based on the previous studies, the 19 th century in the context of the history of religion development in Indonesia was characterized by the existence of two exciting phenomena. The first was the Islamic revival in some areas among the Indonesian archipelago. This phenomenon actually showed us the religious awareness in our indigenous communities was getting increased, all at once this also showed us to the increasingly widespread influence of Western life. As a response to these conditions emerged a strong opposition, especially from religious leaders (Poesponegoro \& Notosusanto, 1993: 148). The second was reintroduction of Catholicism after being prohibited by the VOC. Under the rule of VOC that was closer to the religious traditions of the Protestant, especially Calvinist, Catholic missions in the islands of Indonesia was officially pro- 
hibited (Rosariyanto, 2009: 18-23; Shihab, 1998: 32). Thus, in the 19th century appeared two mainstreams in the religious life of colonial society, the revival of Islam and Catholicism. (Ricklefs. 1984: 13) Two of the above phenomenon occurred in several regions in Indonesia as well as in Java. (Kartodirdjo, 1978).

In late of the 19th century and the beginning of the 20th century, most the island of Java was stricken Islamic revivalism movement. This phenomenon was seen from the fact of increasing number of Javanese pilgrimage, the increasing volume of traditional education, and establishing the branch congregations (Ricklefs, 1998: 198; Steenbrink, 1984: 249-253; Kartodirdjo, 1984: 228). The development a large number places of worship also marked the phenomenon of Islamic revivalism. Snouck Hurgronje reported that in the center of government, such as the capital district, there was Great Mosque. In addition, in some districts was found a mosque with smaller size (Hurgronje, 1973: 18). It can be connected with a number of proposed new mosques in several areas in Java in this period (Pijper, 1984: 15).

The revival of Islamic preaching that struck Java, as had been described, emerged almost the same time with the expansion of mission work in this area. In the first decade of the 19th century, Catholic mission allowed the opening of stations in two cities in Java, Semarang (1808) and Surabaya (1810). The mission originally only focused on the spiritual treatment of Europeans. The expansion of new missions for the indigenous conducted in 1894, when Julius Keijzer from Catholic taught the Javanese people in Lamper Semarang.

Colonialism, Islamic revivalism and Catholic not only in national and regional scope of Java, but also occurred in locally cedar. One of the areas in Java, where the revivalism of Islam and Catholicism was growing almost simultaneously is Semarang. In the colonial period, Semarang became the center of Catholic missionary activity in Central Java, as evidenced by the bishops placed in the area since the early opening of Indonesian archipelago for the mission. On the other hand, Semarang is a city that has a Western influence, but instead Islamic $d a^{\prime} w a h$ is growing rapidly, and became the center of seeding the modern Islamic intellectual.

This paper will discuss the development of the Islamic $d a^{\prime} w a h$ and the Catholic mission in Semarang in the period 1894-1942, and then analyze the relationship between these developments with a socio-religious life in this region. The study was began in 1894, when a Catholic mission started early step in the indigenous preaching and at the same time Islamic $d a^{\prime} w a h$ was starting phase of renewal movement. This study ended in 1942, with the end of the Dutch Colonial Government and Semarang fell into Japanese hands.

\section{RESEARCH METHOD}

This study is a historical research that reconstruct the historical past of Islamic missionary activity and the Catholic mission in Semarang. The study began with the collection of resources. The data collection was done by the use of the document. Primary sources used in this study, in the office of the National Archives in Jakarta, such as Memorie van Overgave, Regeerings Almanac, the decrees; Staatsblad van Nederlandsch-Indie, Bijblad van het Staatsblad van Nederlandsch-Indie, Volkstelling. In the library of St Ignatius College annual progress report authors get the mission that De Katholieke Missie In NederlandsIndie: Jaarboek 1929-1941. In Yogyakarta 
Islamic library, the authors obtain annual years documents of "Soeara Moehammadijah Newspaper" "Hindia Timoer" a magazine published locally contemporaries Semarang, Selompret Melajoe newspaper, Swara Islam and Perhoeboengan magazine are used as a source of comparison of documents and manuscripts. The Advantages of these sources, provides information about the daily life of people in different social strata. However, both sources also have drawbacks, namely the style of the newspapers and magazines were short and fragmented, so it is only able to give a little information about specific events and biographical notes culprit. To compensate for this, it is also used oral source of people who are still able to provide an overview of the social and religious life of the people in the colonial times up to 1942. The information obtained in this study is the collective memory of people about the event, social conditions, activity Islamic missionary and Catholic mission in Semarang. In addition, photo as historical sources also supports this study. Photography colonial always save a lot of story behind it. Photos able to convey the idea of reality and the ideas of truth and enrich the historical narrative and to show how the existence of authorities and residents of the city as well as the religious life of the community.

The step in the historical method after the author collect the data is source criticism, both external and internal. The document issued by the government such as Memorie van Overgave, Regeerings Almanac, Besluit; Staatsblad van Nederlandsch-Indie, Bijblad van het Staatsblad van Nederlandsch-Indie and Volkstelling about Semarang generally trustworthy. This document was created by the authorities is the relevant data to the legality and rationality of bureaucracy. At this stage, the authors conducted a veri- fication process documents or materials which are often referred to as collation, comparing between several documents about the facts sought, so it will look as well as their suitability contradiction between facts. In cases where the facts are contradictory, the authors make the selection on the degree of reliability of the source, by selecting the primary source. Thus, it is a fact of history that can be justified originality. The next step was perform interpretation or analysis. In the process of this interpretation, the authors tried to find and develop a relationship of cause and effect in accordance with the order of occurrence of any fact. Facts are then linked in a logical unity which produces historical story.

\section{RESULT AND DISCUSSION}

\section{Islamic $D a^{\prime} w a h$ and Catholic Mission in Semarang}

The end of the 19th century was an important period in the Islamic growth in Semarang. At this period had been going an important process, which encouraged the birth of "institutionalization scholars" (Dhofier, 1994: 61). The institutionalization of scholars can be seen as a concrete manifestation of the dynamics in the Muslim community, as well as simplification of the position and orientation of human behavior was expected. It was characterized by the establishment of Islamic schools in Semarang and the emergence of religious scholars as a social elite who played important role in forming Muslim religious life.

During the last decades of the 19th century, the Islamic revivalism movement showed a significant increase in religious activity in the area of Semarang. In popular form, this phenomenon was demonstrated by the 
spread of which was filled with virtue and brotherhood that were consolidated in the congregation. At the end of the 19th century, the Sufi congregation Naqsabandiyah as association of the most widely followed by the Muslims in Semarang, especially among the lower classes. The congregation evolved in the region Semarang with propaganda $\mathrm{H}$. Abd. Al Kadir in the 1880s (Bruinessen, 1996: 106). Classified as rapid development of this congregation, it was supported by the expansion da'wah which done by preaching traveled from one place to another.

Furthermore, the Islamic revival manifests itself in the form of an increasing number of schools. Before the 19th century, in Semarang there was only one Islamic educational institution, namely Pesantren Dondong Wetan. As demand for religious learning for Muslims in Semarang and its surroundings increasing, at the end of the 19th century, established two schools in this region by Kiai Saleh Darat, Pesantren Darat and Pesantren Ad-Dainuriyah. This first Islamic traditional school was established in the Land of North Semarang in 1870, while the Ad-Dainuriyah was built in Sendangguwo. About when Pesantren Ad-Dainuriyah exactly was stood not known exactly, but most likely boarding up a few year after Pesantren Darat. The information about these schools in 1880 stated that schools were managed by KH Abdullah Sajad, a beloved santri Kiai Saleh Darat (Salim, 1995: 159).

The end of the 19th century became the early emergence of intellectual works in Semarang, which had not appeared in the previous century. This progress at first was marked by the translation of Arabic books into the Javanese language. In Semarang, despite it was not perfect the work of translation had appeared in 1869 in a book called Fathul Qarib (Anasom, 2003: 134). Work of translation, further appeared in the paper of Kiai Saleh Darat, namely Sabil al Abid 'ala al-Tawhid Jauharah. Besides the work of translation, in Semarang also be found the work of interpretation of the Qur'an, namely Faidh al Rahman. This interpretation works composed by Kiai Saleh Darat in Javanese language (Muchoyar, 2000).

The emergence of intellectual work with Javanese language in Semarang at the end of the 19th century, at least showed the two important character of missionary movement in Semarang, which concerned local values and instead of milinearism movement. In this context, the Islamic $d a^{\prime} w a h$ in Semarang had a different position than $d a^{\prime} w a h$ in other areas, which tended to be puritanical and confrontational. These strategies were taken by considering the social conditions of society, which generally belonged to nonexpert in mastering Arabic. This could be seen from the Preamble of the book Matn al Hikam which was written by Kiai Saleh Darat in 1872 AD.

Kiai Saleh Darat, as stated "is one of an important link connecting the tradition of Islamic education". Through the activities of Islamic studies at the pesantren Darat, was born reformers figures as agents of change in Islamic societies in the 20th century, in which $\mathrm{KH}$ Ahmad Dahlan (the founder of Muhammadiyah) and $\mathrm{KH}$ Hashim Ash'ari (NU founder). Thus, the development of Islam in the late 19 th century in Semarang, became historical foundation for the emergence of reform movements in this region in the middle third decade of the 20th century.

Islamic $D a^{\prime} w a h$ in the beginning of the 20th century, faced with increasingly complex challenges. At that time, the progress became dominant discourse among the urban community, especially among Western-educated elite. At the same time, enthusiasm for change also 
owned by the perpetrators of $d a^{\prime} w a h$ in Semarang. Borrowing the term from Kuntowijoyo, it appeared a change in pattern of Islamic $d a^{\prime} w a h$ in Semarang "from communal to associational patterns". (Kuntowijoyo, 1999: 195). At this time, the effort to reform schools and congregations conducted. In addition, the renewal movement and dynamic reformer which were also starting to grow in this city. The movement was growing in order to fight against four enemies, old-fashioned formalism, traditional culture and prijaji, westernized attitude, and status quo of occupation (Benda, 1980: 72).

At the beginning of the 20th century, it was observed unique phenomenon, which was the city started shift the role of the villagers as a community of change, and the Semarang including those that involved in the process of change. The existence of internal dynamics in society and the introduction of new ideas about the organization and form of a new leadership and new awareness of identity, had influenced the perspectives of $d a^{\prime} w a h$ movement in Semarang in looking himself and their future. This case could be seen as shown in from of the growth of Islamic reform movements in Semarang, like sarekat Islam (SI), Muhammadiyah and Nahdlatul Ulama (NU). Through the modernist Muslim organizations and Islamic educational institutions below, $d a^{\prime} w a h$ movement simultaneously performed reformulation and reinterpretation of Islamic in the context of "Indonesianness and modernity".

On the other hand, until the end of the 19th century, the number of Catholics in Java, including Semarang was dominated by Europeans and Eurasia. Until the early 1890's, it had not been seen a serious effort to attract the indigenous to be Catholicis. Several plans were made, but no one became a reality.
The mission among the Javanese, just begun in 1894 when J. Keijzer began to teach the Catholic faith to the Javanese people in Lamper Semarang and Bedono (Rosariyanto, 2009: 99).

The mission among the Javanese, which had started in 1894, then developed into a movement towards the Catholic faith. This year, two Protestants, that they were Martinus Martodirejo and Joannes Vreede declared becoming Catholic. Both men were proficient in Malay and Javanese, so they were often asked for help as an interpreter for the Dutch missionaries. (Sugiri, 1958: 28). There were no obvious reasons concerning the reasons about the conversion of Javanese missionary to the Catholic. In the KAS team record, was mentioned that the missionary, like Joanes Vreede dismissed from the missionaries because of dishonest. (Tim KAS, 1992: 18) Different opinions expressed by van Lith, which stated the conversion of Javanese catechist became a Catholic, because of the followed Teffer. Regardless of the unclear reason for the conversion of Protestant missionary into Catholic, in the further development the existence of Javanese catechists had paved the way for the movement towards Catholicism among the Javanese people in Semarang and surrounding areas.

Julius Keijzer, thus called as a mission superior as well as pioneer missionaries to the Javanese in Semarang. Keijzer saw that the mission among Javanese looked very promising. Then, in 1894, a course for Catholics' teachers was established in Semarang (Steenbrink, 2006: 364-366). Furthermore, in 1894-1895, there were registered 234 Javanese people in Semarang and Bedono who turned to be Catholics. (Tim KAS, 1992: 28). In terms of quantity, the number of the Javanese people who turned into Catholic showed a fan- 
tastic data. However, as mentioned in many stories of the mission, apparently the number of Catholic baptism in Bedono was merely fictitious only.

The development of Catholic's mission for Javanese was a burdensome for Keijzer who was served as a mission superior of Jesuit and at the same time also served as the head of priest in Semarang. Therefore, as a superior mission, Keijzer asked G. Hellings from Maluku to work together among the Javanese people in Semarang. In January 1895, Hellings arrived in Semarang and started learning Javanese language. At the end of 1895, he had published a handbook of worship for Javanese Catholics entitled Kitab Sembahjang Tjilik Kanggio The Wong-Katolika Room. At about the same time, Keijzer assigned Hebrans to learn Javanese language and to help Hellings.

While the mission among the Javanese people ran well, Keijzer's condition of health was getting worst, so he had return to Holland for doing his treatment. In the middle of his treatment efforts in Netherlands, Keijzer passed away on September 17, 1896. The result of Keijzer's works could be seen in 1896 when the mission of Java had already had two Catholic elementary schools at Mlaten and Lamper. These schools meant for men and women, Catholic and non-Catholic. In addition, the activity of the native mission in Semarang showed an improvement, as shown in the statistics on the number of Catholics, although the amount had not been a lot in quantity. The Statistical data of the Archdiocese of Semarang in 1900 showed that Catholics at parish of Semarang in 1900 amounted to 3017 people, by details of the 2853 Europeans, 18 Chinese and 146 natives (Tim KAS, 1992: 15). It was known that native Catholics at parish of Semarang was the largest compared to the number of na- tive Catholics at other parishes in the Archdiocese of Semarang.

The early work mission for natives in Semarang could be said to have a good fortune, in the middle of the perceived impasse for about four decades. This impasse illustrates how difficult the mission expands the range of its services among the natives (Sudiarja, 1959: 27). The above condition begun to change, when at the end of the 19th century Catholic mission gained momentum shift of luck by the Protestant missionary to be Catholic. Furthermore, the former missionary became catechist Catholic and contributed in spreading the Catholic in the Javanese community at Semarang and surrounding areas.

The existence of catechists, as the power assistance be formal and permanent, had contributed to the extraordinary work of missions. Catechists, in accordance with their capabilities, served as teacher and propagandist. They gave lessons to the catechumens, and built relationships with people which were not familiar with Catholic. These catechists had a comparative advantage compared to the missionaries that was emotional and cultural proximity to the community. Therefore, in further developments, the catechists' propagandists took the role as opening the way for missionary presence.

Catechists, along with the priests, brothers and sisters in their capacity played a role in expanding the nets missions in the community. The existences of the priests, since the beginning of the 20th century continued to grow in number, affecting an increasing intensity of preaching and pastoral visits. This case conducted via social contacts with people, religious instruction, as well as the celebration of the Eucharist in a more regular basis. Likewise with presence of the brothers of the congregation of St. Aloysius and the Sisters of the Order 
Franciscan, this worked through each field of the workmanship, tried to expand the missions of coverage for indigenes at Semarang.

\section{$D a^{\prime} w a h$ and Mission: Responding to- ward New Challenges}

Semarang city, in the 20th century, was marked by the emergence of new socio-cultural reality. This condition arose, as a result of social change, which in some circumstances consistent with the Catholic mission was intensified provide concrete services to the community, as well as the birth of a new consciousness among $d a^{\prime} w a h$ supporters. At this time the desire for change and renewal became something that was not inevitable. Progress became a dominant discourse, particularly among the urban community. During this period, emerged new and important phenomenon in the structure of modern Muslims, that Islamic associations which were marked based on the establishment of Islamic reform organizations such as the Sarekat Islam, Muhammadiyah and Nahdlatul Ulama.

Existence of the organization as mentioned above, gave birth to a pattern of life based on the spirit of progress and brought new awareness in eliciting creativity to respond socio-economic growth. The existence of this movement, on one side served as a substitution for those increasingly primordial ties worn, and at the other side of the foundation stone of new community. In this context, there had been a widening of the concept of a functional community. The existence of these organizations to create new social realities that brought structural changes. The existence of a wide range of organization had provided a channel for social mobility patterns that resulted the emergence of new leader- ship style. It was seen from new board election process undertaken through the mechanism of the general meeting by the SI Branch of Semarang on 18 April 1915 (Sinar Djawa No 56 March 9, 1915). In addition, the presence of Muhammadiyah and its autonomous organizations, such as Penolong Kesengsaraan Oemoem (PKO), Aisyiyah, and the Muhammadiyah Youth recruit members of the leadership by consensus. This could be seen from the implementation of the general meeting of Muhammadiyah Semarang Section Aisyiyah on December 13,1931 . In the forum, the new management Aisyiyah Semarang Branch, was chosen and defined, namely: chairman (Mrs. Siroen), Secretary (Mrs. Soebandijah), Treasurer (Mrs. Soetedjo), the Commission (Mrs. Soeratno), and commission members (Mrs. Soetrasno) (Swara Islam No 2, December 1931).

The phenomenon of social mobility among Muslims in Semarang as described above, showed the golden period of the great scholars who have (had) strong charisma, as in the Kiai Saleh Darat, getting closer to the end. Charismatic leader that binds followers with a direct, personal relationship and emotional, started side by side with leaders seeking legitimacy at rationality of the organization and integrity of thought. Taufik Abdullah called this phenomenon as the deployment of authority (Abdullah, 1996: 250).

Catholic mission activity among native Semarang had created new challenges which further were responded well by the mission. This was seen from the growth of these new institutions in education. At the beginning of the first introduce Catholic doctrine in Semarang, institutions, schools become one of the medium to convey the gospel. In the middle of the provision of educational disparity between European children and natives in Semarang as well as visu- 
alized by Sinar Jawa newspaper, Catholic the mission successfully took the opportunity by provide educational facilities for the natives. Therefore, unsurprisingly that the mission in the education sector earned success and became the backbone for growth in the number of Catholics in Semarang (Sinar Djawa No 289, December 22, 1915).

Catholic Mission, besides applying the Western model of education had also introduced modern health services. The working Health of the Catholic mission were an integral part of his ministry. In historical records Catholicism the mission in Semarang, not a few missionaries, monks, nuns, and laymen which devoted himself in his health. The missionaries began to introduce new models of health services for the community, namely the model of treatment in hospital. Mission in health implemented in 1927, when a Catholic hospital called St Elisabeth opened in the Candi hill of Semarang. The hospital was built at the initiative of some of the nuns of the Order of Saint Francis (OSF), based in Gedangan. The development of health facility, such as hospitals, readable as an expression of social commitment of the Catholic mission.

Catholics in Semarang, in historical track moved through the formation of various organizations. At first the organization was formed by the Dutch, but since 1920-an organization that embodies the aspirations of Catholics also developed by Java. This could be seen from the development of social associations in the churches's mission of Java, namely Pangruktilaya. This society handle death, ranging from caring for the body to organize the funeral. According to data from 1933, in Semarang associations already has 81 members (Anonim, 1934: 24).

In Semarang, besides Pangruktilaya, also stood another social club, name- ly Katolik Wandawa (KW). Not obtained definite information yet about when the establishment of this associations. Data obtained from Swara Tama newspaper stated that in late 1929, KW has (HAD) members a number of 45 people. This association activied include preparing the purposes of worship the people who would follow the Mass, Easter, and Christmas (Swara Tama No 7, February 13, 1931). This was as shown of role caretaker in animate KW Christmas in 1930 in Semarang, which was centered in the presbytery Randusari. Christmas celebrations in the year had been done by the committee which helped some board, chaired by R. KW M. Sasraningrat. (Swara Tama No 1, January 2,1931$)$.

In the track of history, the development oaf's mission cannot be separated from the role of women. The establishment of women's organizations like Catholic Women could be seen as a form of women's response to the movement growth's mission and development of civilization. Swara Tama reported that with the support of PPKD, Melania, and the Catholic Women of Yogyakarta, Semarang Catholic Women finally officially established on May 17, 1931. In the meeting establishment, RA Sasraningrat was elected as a chair of Catholic Women Semarang (Swara Tama No 35, August 28, 1931).

Another association that developed in Semarang was the Young Catholicism Parish. Through this associations, the Javanese Catholics young man, can (could) channeled social and religious activities, as well as strengthen brotherhood. Together they built themselves based at a specific vision and mission. Missionary life coaching activities for young people was also reflected in the student associations, namely Palupi Darmo. This association was first established in Muntilan in 1925, the purpose 
The New Responds ... - Mukhamad Shokheh

of helping the young men who were undergoing priestly education, through prayer and funding. These students involved in the creation of the native pastor. The number of members Palupi Darmo at Semarang in 1933 based on the record as 30 people (Anonim, 1934: 24).

Among the associations young man among the Catholics, the Catholic Youth associations known as the most widely spreading. Associations which stand at Yogyakarta in 1929, consisted of several groups. In the school, there were three groups, one each for students standart school, HIS / ELS, and MULO, whereas at the work environment, there are two groups of workers to speak Javanese and Dutch-speaking workers (De Katholieke Missie Jaarboek 1937: 276-277). Reason the possibility of grouping based on the social nature of these associations. Young Catholics had had some branches in some areas. Young Catholics in Semarang in 1933, had a number of members of as 33 people. (Anonim, 1934: 24).

The natives Catholic, besides developed socio-religious organization, also established the cooperation to develop the economy for his people. The cooperation that only reserved for native Catholics was called Among Mitra. Regarding this cooperation activity, Swara Tama reported that on 20 September 1931 took place in presbytery Randusari held meetings with an agenda establishment of cooperation, endorsement AD / ART, and the selection committee. The composition of the board who was appointed: chairman (Sasraningrat RMJ), and concurrently secretary of the treasury (RC Dibjaatmadja), administrator (AJ Soeratmo), and assistant administrator (SS and RFJ Notoredjoso Sapardal) (Swara Tama No 39, September 25, 1931).

\section{CONCLUSION}

Revivalism which took place among Muslims and Catholics in Semarang had some similarities, including presenting symptoms of increased missionary activity, appreciation of local values, and did not raise millennialism movement. Nevertheless, both had different historical experience, Islamic revivalism in the process more feature improved quality of faith, although it could not be denied that religious conversion was also still ongoing. This differs with that Catholic revivalism favor of "religious conversion, and then followed with care the faith". Therefore, the influence of both phenomena on the activity $d a^{\prime} w a h$ and missions were different, as seen from the manifestations of the movement in the field. Islamic $d a^{\prime} w a h$ was greater emphasis on religion and the spirit of renewal to achieve authenticity. On the other hand, mission brought the spirit of progress to offer new value and innovation in various fields, such as education, health, and social. In addition, the mission expansion was more scalable and could be quantified. This differs with the intensification of Islamic $d a^{\prime} w a h$ that tended to be qualitative.

Activities of $d a^{\prime} w a h$ and missions that took place at Semarang in 1894-1942 have brought progress to the social life of religious communities. During this period, there were structural changes within the community. Community began to recognize the leadership of religious organizations and forms of new leadership that more rational and democratic. In addition, the activity of $d a^{\prime} w a h$ and mission began to encroach on help provide a foundation for the political growth of national and state consciousness. This development could be seen as a continuation of Islamic revivalism and Catholic held on the previous period. 


\section{REFERENCES}

Abdullah, Taufik. 1996. Islam dan Masyarakat; Pantulan Sejarah Indonesia. Jakarta: LP3ES.

Al-Samarani, Muhamad Shalih. Tanpa tahun. Matn al Hikam: Kitab Penjelas al Hikam Karya al Syaikh Ahmad bin 'Athaillah al Sukandary. Semarang: Toha Putra.

Anasom. 2003. “Dakwah Islam di Semarang Akhir Abad XIX: Telaah Historis Terhahap Rijjal Al-Dakwah". Tesis. Yogyakarta: Program Pascasarjana Universitas Gadjah Mada.

Anonim. 1934. Wat Doen De Katholieken Te Semarang. Semarang: G.C.T. Van Dorp \& Co.

ANRI. 1977. Memori Serah Jabatan 1921-1930 (Jawa Tengah). Kakarta: ANRI.

Bruinessen, Martin van. 1996. Tarekat Naqsabandiyah di Indonesia. Bandung: Mizan.

Chys, Van Der. 1864. "Bidragen tot de geschiedenis van het inlandsch onderwijs in Nederlandsch-Indie", in Tijdschrift voor Indische Taal, Land en Volkenkunde, vol XIV Tahun 1864.

Darban, Ahmad Adaby. 2004. Rifa'iyah: Gerakan Sosial Keagamaan di Pedesaan Jawa Tengah Tahun 1850-1982. Yogyakarta: Tarawang Press.

De. R.K. Kerk in Nederlandsch Indie (Missiealmanak 1929). Djogjakarta: Canisius, 1929.

De Katholieke Missie In Nederlands Indie Jaarboek 1937-1941. Batavia: Centraal Missie Bureau.

Dewan Paroki Katedral. 1977. 50 Tahun Paroki Katedral Semarang. Semarang: Paroki Katedral

Dhofier, Zamakhsyari. 1994.Tradisi Pesantren: Studi tentang Pandangan Hidup Kyai. Jakarta: LP3ES.

End, van den. 2006. Ragi Carita 1: Sejarah Gereja Di Indonesia 1500-1860, Jakarta: BPK Gunung Mulia.

Horikoshi, Hiroko. 1987. Kyai dan Perubahan Sosial. Jakarta: P3M.

Hurgronje, Snouck. 1973. Islam Di Hindia Belanda. Jakarta: Bhratara.

Israeli, Raphael and A.H. John (ed).1984. Islam In Asia Volume II Southeast and
East Asia. Jerusalem: The Magnes

Press The Hebrew University.

Kartodirdjo, Sartono. 1978. Protest Movement in Rural Java. Kuala Lumpur: Oxford University Press,.

------. 1984. Pemberontakan Petani Banten 1888: Kondisi, Jalan Peristiwa dan Kelanjutannya Sebuah Studi Kasus Mengenai Gerakan Sosial di Indonesia. Jakarta: Pustaka Jaya.

Kuntowijoyo. 1999. Paradigma Islam: Interpretasi Untuk Aksi. Bandung: Mizan.

Muhammad, Djawahir (ed). 1995. Semarang Sepanjang Jalan Kenangan. Semarang: Pemkot- DKJT.

Peringatan 50 Tahun Rumah Sakit St Elizabeth, Semarang: Panitian HUT RS St Elizabeh, 1977.

Pijper, GF. 1984. Beberapa Studi Tentang Sejarah Islam di Indonesia, Jakarta: UI Press.

Poesponegoro, Marwati Djoened dan Nugroho Notosusanto (ed). 1993. Sejarah Nasional Indonesia IV, Jakarta: Balai Pustaka.

Putuhena, M. Shaleh. 2007. Historiografi Haji Indonesia. Yogyakarta: LKIS.

Ricklefs, M.C. 1998. Sejarah Indonesia Modern. Yogyakarta: Gadjah Mada University Press.

------. 2007. Polarising Javanese Society: Islamic and Other Visions c. 1830-1930. Singapore: NUS Press.

Rosariyanto, F. Hasto. 2009. Van Lith: Pembuka Pendidikan Guru di Jawa Sejarah 150 th Serikat Jesus di Indonesia, Yogyakarta: Universitas Sanata Dharma.

Sugiri, C. 1958. Stasi Semarang Antara 18481908, dalam Satu Setengah Abad Geredja Katolik di Semarang. Semarang: Panitia Pusat Jubileum Satu Setengah Abad Stasi Semarang.

Shihab, Alwi. 1998. Membendung Arus: Respons Gerakan Muhammadiyah Terhadap Penetrasi Misi Kristen di Indonesia. Bandung: Mizan.

Steenbrink, Karel. 1984. Beberapa Aspek Tentang Islam di Indonesia Abad ke-19. Jakarta: Bulan Bintang. 2006. Orang-Orang Katolik Di Indonesia 1808-1942. Jilid 1: Suatu Pemulihan Bersahaja 1803-1903. Maumere: Leladero. 
The New Responds ... - Mukhamad Shokheh

Sudiarja, A. tanpa tahun. Seratus tahun Misi: Misi Sarekat Jesus di Indonesia 1859-1959. Jakarta: Tanpa Penerbit.

Suminto, Aqib . 1985. Politik Islam Hindia Belanda. Jakarta: LP3ES.

Suryo, Djoko. 1989. Sejarah Sosial Pedesaan Karesidenan Semarang 1830-1900. Yogyakarta: PAU SS Universitas Gadjah Mada.

Tim Edukasi MMM PAM, Lahirnya Gereja Katolik Keuskupan Agung Semarang, Muntilan: Museum Misi Muntilan Pusat Animasi Misioner, 2008.
Tim KAS, Garis-Garis Besar Sejarah Gereja Katolik Keuskupan Agung Semarang, Semarang: KAS, 1992.

Vriens, G. 1972. Sejarah Gereja Katolik Indonesia Jilid 2 (Wilayah Tunggal PrefekturVikariat). Flores: Arnoldus.

Wolterbeek, J.D. 1995. Babad Zending di Pulau Jawa. Yogyakarta: Taman Pustaka Kristen.

\section{Newspaper}

Selompret Melajoe

Sinar Djawa

Perhoeboengan

Swara Islam 